消化器癌の肝転移再発に対する予防法の研究

\begin{tabular}{|c|c|c|c|c|c|c|c|}
\hline & & 宫山医科 & 科大学 & 外科，“ & RI 施 & & \\
\hline 笠木 & 徳三 & 田沢 & 賢次 & 山下 & 䉷 & 石沢 & 伸 \\
\hline 増山 & 喜一 & 藤巻 & 雅夫 & 前田 & 正敏* & 本田 & 曻 \\
\hline
\end{tabular}

\title{
A STUDY ON THE PROPHYLACTIC MEASUROS FOR THE HEPATIC METASTATIC RECURRENCE OF THE GASTROINTESTINAL CANCER
}

\author{
Tokuzo KASAGI, Kenji TAZAWA, Iwao YAMASHITA, \\ Shin ISHIZAWA, Kiichi MASUYAMA, Masao FUJIMAKI, \\ Masatoshi MAEDA* and Takashi HONDA* \\ Second Department of Surgery, Radio-Isotope Laboratory*, \\ Toyama Medical and Pharmaceutical University
}

\begin{abstract}
消化器悪性腫㾤の肝転移再発に対する予防的な治療を目的として OK-432を中鎖脂肪でェマルジョ ン化して経口投与し，その効果を実験的，踟床的に検討した。畽瘍細胞 AH60C を用いたラットの肝転 移実験に扎いて，OK-432中鎖脂肪エマルション経口投与群の転移抑制率は $57.1 \%$ で，無処置群之の間 に有意差を認めた。細胞障害活性試験では OK-432中鎖脂肪エマルショョン経口投与群は, 腸間膜リンパ 節 $43 \%$, 脾細胞 $50 \%$, で水溶液投与群より高い傾向にあった。臨床例では OK-432中鎖脂肪エマルショ ン経口投与により NK 活性の低い担癌患者 5 例中 3 例が正常值に復した。 また OKT4/OKT8比が上 昇した。以上より，OK-432中鎖脂肪ェマルジョン経口投与の有用性が示唆された。
\end{abstract}

事引用語：肝転移再発の予防, OK-432, 中鎖脂肪ェマルジョン, biological response modifier, ラットの実験的肝転移

\section{はじめに}

悪性腫瘍の最も重要な特徵は転移能を有すること, すなわち原発巣からかけ離れた部位に腫瘍を形成する ことである．消化器癌においては，根治手術後に肝転 移のかたちで再発する，いわゆる肝転移再発は予後を 左右する重大な因子である。近年の転移に関する研究 はめざましく, 消化器癌の肝転移に対する治療法が多 数報告されている。われわれは肝転移の治療のひとつ として予防的治療を検討してきた。この概念はすでに 形成され大きく発育した肝転移に対しての治療と異な り, 手術時に肉眼的には見出だせない転移, すなわち 微小転移宩や，手術操作による腫瘍細胞の遊離をきっ かけとした転移巣の形成, あるいは手術侵襲による免 疫能の低下による腫㾴の増殖能の増強を抑制すること であり,これからの癌治療には久かせないものとい

$<1989$ 年 6 月 7 日受理 >別刷請求先：笠木 徳三 干930-01 富山市杉谷 2630 富山医科薬科大学第 2 外 科
えよう.このような治療には biological response modifier (BRM)は最も適したものの 1 つである1). わ れわれは BRM の代表的な1つである OK-432を用い て肝転移再発の予防的治療を検討してきだ2). OK432の投与法には種々の方法が報告されているが, 経口 投与は重篤な副作用もなく, 比較的大量を反復してし かも長期間にわたり投与できる利点がある，OK-432 を,門脈系に直接移行するとされている中鎖脂肪 (medium chain triglyceride, 以下MCT) でェマル ジョン化し経口投与を試みたところ, 実験的肝転移に 対し良好な成績を得た、臨床においてもとの有用性を 示唆する結果を得たので報告する。

\section{材料・対象およひ方法}

1. OK-432 MCT エマルジョンの調製

油層として MCT (ミグリオール812), HCO-60 (ポ リオキシエチレン硬化ヒマン油誘導体), MGS-B(グリ セリンモノステアリン酸誘導体), 水層として OK-432 水溶液を $60^{\circ} \mathrm{C}$ 加温し， 1 万回転以上で 5 分間ホモゲ 
ナイズして OK-432 MCT ェマルジョンを調製した (図 1).

\section{2. ${ }^{99 m}$-TC-OK-432の調製}

OK-432 (5.0KE) 水溶液を $0.1 \mathrm{~N} \mathrm{HCl}$ で $\mathrm{pH}$ 1.5〜2.5にする.これに0.1N HCl $50 \mathrm{ml}$ に $\mathrm{SnCl}_{2}$ を $100 \mathrm{mg}$ 溶解した試薬 $0.5 \mathrm{ml}$ 加兄る。つぎに ${ }^{99 \mathrm{~m}} . \mathrm{TcO}_{2}$ 水 溶液 $1 \mathrm{ml}$ を加えて 15 分間放置したのち0.1N NaOH で $\mathrm{pH}$ 約 5.5 に調節した. MCT エマルジョンは標識され

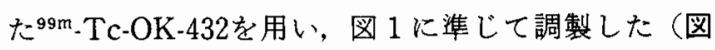
2 ).

3. 経腸的投与された ${ }^{99 \mathrm{~m}}-\mathrm{Tc}-\mathrm{OK}-432 \mathrm{Sn}$ コロイドの 門脈血中濃度の測定

1 日絶食させた雄性ドンリュウラット（300g）6匹 を2群にわけ, ${ }^{99 m}$.Tc-OK-432 MCT ェマルジョン投 与群と ${ }^{99 m}$-Tc-OK-432水溶液投与群とした。ネンブ タール麻酔下に開腹し, 胃液, 胆汁による OK-432の変 質や99m-Tc が OK-432から遊離される可能性を考慮し 十二指腸にカニュレーションし，これより投与した。 また，カニューレより口側の腸管は結禁した。1匹あ たりに投与した ${ }^{99 m}-\mathrm{Tc}-\mathrm{OK}-432$ の比活性放射能は $2 \mathrm{mCi}$ (5.0KE) とした. 投与 5 分後から 90 分後まで経時的に 門脈血を採取し，その放射能活性はガンマーカウン

図 1 OK-432中鎖脂肪エマルジョンの調整

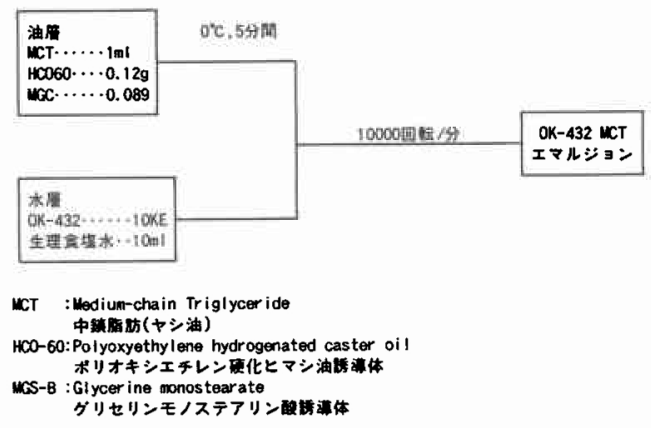

図 $2{ }^{99 m}$ Tc-OK-432 Snコロイド溶液の調整

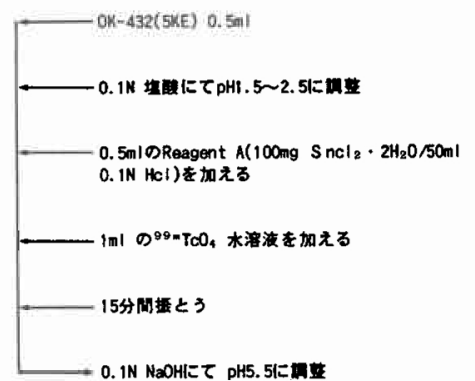

ター (Auto well, Aloka 社製) により測定した。

4. ${ }^{99 m}$.Tc-OK-432の体内臓器分布

雄性ドンリュウラット（300g）4匹を2 群にわけ， それぞれの群に ${ }^{99 \mathrm{~m}}$-Tc-432 MCT ェマルジョンまたは 水溶液を経腸管的に投与し 90 分後に屠殺して各藏器の 放射能活性を測定した。 1 匹あたりの ${ }^{99 \mathrm{~m}}$-Tc-OK-432 の比活性放射能は $2 \mathrm{mCi}(5.0 \mathrm{KE})$ とした.

5. OK-432-MCT ェマルジョンおよび OK-432水溶 液経口投与における細胞障害活性の測定

$\mathrm{C} 3 \mathrm{H} / \mathrm{He}$ マウスを 3 群にわけ(各群 5 匹), それぞれ の群に OK-432(0.5KE) MCT $432(0.5 \mathrm{KE})$ 水溶液, 生理食塩水を 0 日目, 3 日目に 金属カニューレで胃内に投与した。 4 日目に屠殺し, 脾細胞, 腸間膜リンパ節, 腹腔浸出細胞の細胞障害活 性を測定した。測定の方法は，標的細胞としてYAC-1 を用いEffector/Target ratioは50：1とし, ${ }^{51} \mathrm{Cr}$ 遊 離法にて行った。

\section{6. 実験肝転移の抑制効果の検討}

OK-432 MCT エマルショョン経口投与による肝転移 抑制効果を実験モデルを用いて検討した。肝転移モデ ルは教室で樹立した方法2)，すなわち腫汮細胞 AH60 $\mathrm{C}^{4) 5)}$ 約 $2.5 \times 10^{6}$ 個/rat に注入し, 肝に転移巣を形成せしめる方法にて作成し た. 5 週齢 $(140 \sim 160 \mathrm{~g})$ の雄性ドンリュウラットを 3 群にわけ，第 1 群は OK-432 MCT エマルジョン投与 群, 第 2 群は OK-432水溶液投与群, 第 3 群は対照群と した. OK-432投与群には AH 60C の門脈内注入前に 2 回 $(0.5 \mathrm{KE} \times 2 /$ 週 $)$, 注入後に 8 回 $(0.5 \mathrm{KE} \times 2 /$ 週 $)$ 金 属カニューレで胃内に投与した。第 3 群は腫崲細胞 250 万個の門脈内注入のみとした。これら 3 群を30日後に 屠殺し、肝転移の有無を検討した（図 3 ).

7. OK-432 MCT ェマルション経口投与における健 常成人の NK 活性の変化

21 23歳の男性健常成人に OK-432 MCT エ ル

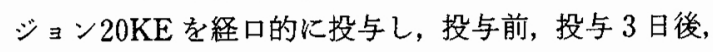

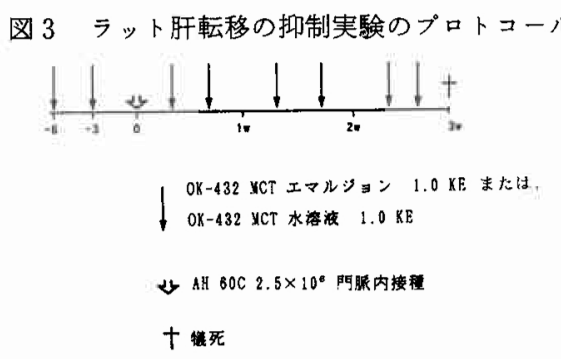


投与 7 日後に末梢血の NK 活性を測定した。

8. OK-432 MCT ェマルジョン経口投与に打ける大 腸癌患者の術前・術後の NK 活性の変化

画像診断上, 肝転移のない大腸癌患者 12 例（結腸癌 6 例，直腸癌 6 例）を対象とした。手術 3 日前および 術後10日目にOK-432 MCT エマルジョン $20 \mathrm{KE} / 20 \mathrm{ml}$ を投与し，末梢血の $\mathrm{NK}$ 活性を投与前，投与 3 日後， 手術 3 日後，7日後に測定しその変化を検討した。

9.フローサイトメトリーによる大腸癌患者末佾血 のリンパ球サブセットの検討

画像診断上, 肝転移のない大腸癌患者18例に対し OK-432 MCT エマルショョン上記 8 と同様に投与し, 末梢血のリンパ球サブセットを投与前，投与 3 日後, 手術 3 日後，5 日後，7日後，14日後にフローサイト メーター (EPICS C, Coulter 社製)により解析した.

\section{結果}

1. 調製されたェマルジョンは $\mathrm{O} / \mathrm{W}$ 型でその粒子 の大きさは 1 ～ 3 ミクロンである。また, OK-432の菌 体は大部分がェマルジョンの外水層に分散し，一部が エマルジョン粒子の表面に付着あるいは粒子内にとり こまれていることが認められた（図4）.

2. 調製された パークロマトグラフィにより検定したが，Free 99m. Tc, ${ }^{99 m}$-Tc Sn コロイド, ${ }^{99 m}$-Tc-OK-432 Snコロイド およびェマルジョン調製の操作を加えても年开-Tcが 遊離することなくは注定していた（図５）.

3. ${ }^{99 m}$-Tc-OK-432 MCT × ルショョン投与群にお ける門脈血中の放射能活性は ${ }^{99 m}$.Tc.OK-432水溶液投 与群に比較して, いずれの測定点においても約10倍高 いことが認められた（図6）.

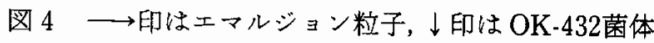
粒子

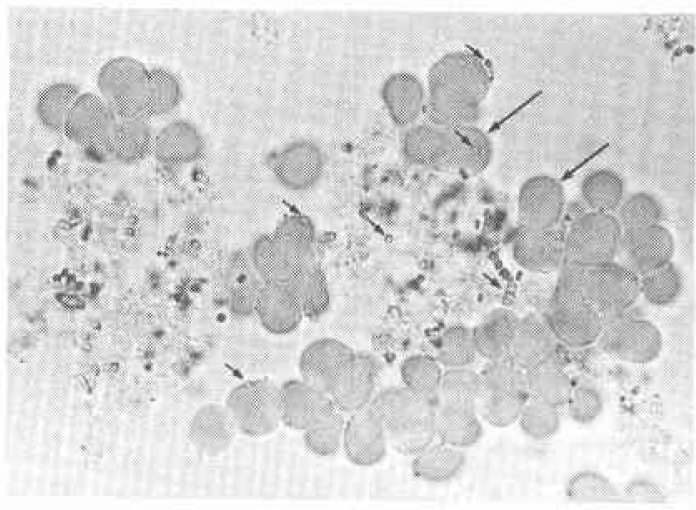

図 5 ペーパークロマトグラフィーによる ${ }^{99 m} \mathrm{Tc}-\mathrm{OK}$. $432 \mathrm{MCT}$ ェマルジョンの安定性の検討

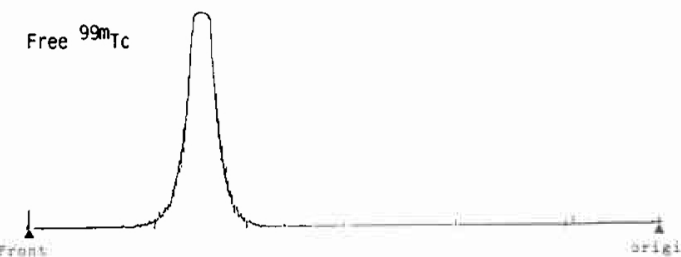

$$
99 m_{T C-0 K-432} \mathrm{Sn} \text { colloid }
$$

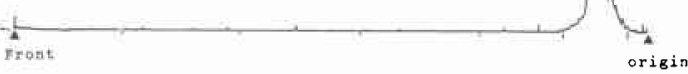

$99 T_{T C-0 K-432}$ KCT Emulsion

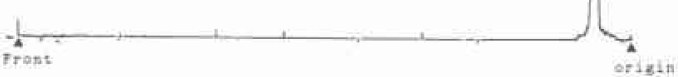

図 $6{ }^{99 \mathrm{~m}} \mathrm{Tc}-\mathrm{OK}-432 \mathrm{MCT}$ ×マルション, ${ }^{99 \mathrm{~m}} \mathrm{Tc}-\mathrm{OK}$. 432水溶液経腸管投与時の門脈血中 ${ }^{99 m} \mathrm{Tc}-\mathrm{OK}-432$ の 経時的変化

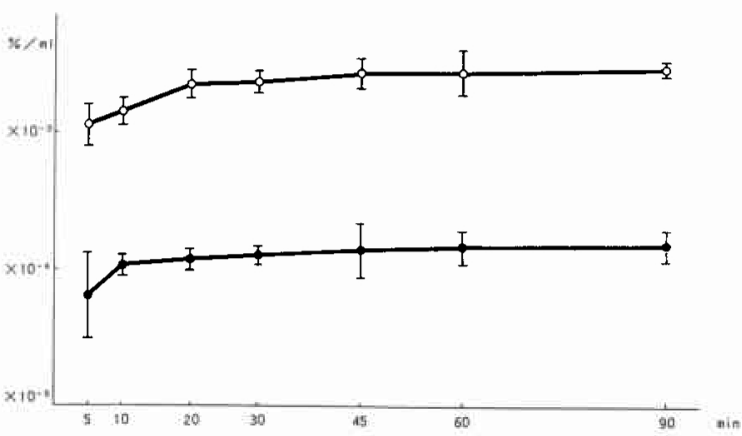

4. 経腸的に ${ }^{99 m}-\mathrm{Tc}-\mathrm{OK}-432 \mathrm{MCT}$ エルジョンお よび，99m-OK-432水溶液を投与された各群に和ける放 射能活性の藏器内分布では, 両群とも肝, 腎に高く認 められた。しかし, 両群の各葴器について比較する と, ${ }^{99 m}$.Tc-OK-432 MCT ェマルジョン投与群は99m. $\mathrm{OK}-432$ 水溶液投与群の約 8.5 倍を示した(表 1, 図 7 ). 5. 腸間膜リンパ節, 脾細胞, 腹腔浸出細胞の細胞障 害活性は, OK-432 MCT ェマルション投与群では,そ 
図 ${ }^{{ }^{99 m}}$ Tc-OK-432経腸管投与90分後の臓器内分布

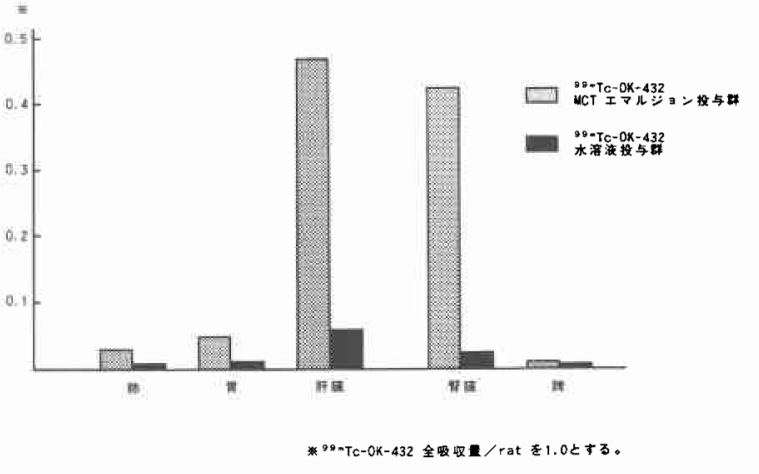

表 1 経腸的（十二指腸より）投与された ${ }^{99 \mathrm{~m}} \mathrm{Tc}-\mathrm{OK}$ $432 \mathrm{MCT}$ ×マルジョンの体内葴器分布

\begin{tabular}{|c|c|c|c|c|c|c|}
\hline & 监位 & 踥 & 角 & 解 & 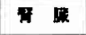 & H \\
\hline $\begin{array}{l}\text { 99-Tc-0K-432 } \\
\text { Мст エマルジョン }\end{array}$ & $\begin{array}{l}\text { OPM } \\
(z)\end{array}$ & & & $\begin{array}{l}16164138 \\
(1.74)\end{array}$ & $\begin{array}{l}15076355 \\
(1.627)\end{array}$ & $\begin{array}{c}346442 \\
(0.0374)\end{array}$ \\
\hline $\begin{array}{l}99-T c-0 K-432 \\
\text { 水楁济 }\end{array}$ & $\begin{array}{l}\text { DPM } \\
(x)\end{array}$ & $\begin{array}{c}19110 \\
(0.0208)\end{array}$ & $\begin{array}{c}316065 \\
(0.0341)\end{array}$ & $\begin{array}{l}1881923 \\
(0.203)\end{array}$ & $\begin{array}{r}1296805 \\
(0.1399)\end{array}$ & $\begin{array}{c}119338 \\
(0.0129)\end{array}$ \\
\hline
\end{tabular}

れぞれ $43 \% ， 50 \% ， 31 \%$ を示し，対象群の約 1.2 倍から 1.5倍の増強を認めた。一方, OK-432水溶液投与群はそ れぞれ，37\%，43\%，32\%であった。 OK-432 MCT ェ マルジョン，水溶液の両群間に有意差はなかった（図 $8)$.

6. OK-432 MCT エマルジョンを投与した第 1 群で は $57.1 \%(8 / 14) ， \mathrm{OK}-432$ 水溶液を投与した第 2 群(同 250万個)では46.1\%（6/13）に肝転移を認めなかった。

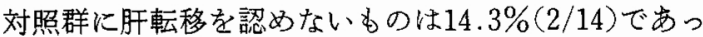
た（表 2$)$ ）第 1 群と対照群とのあいだに有意差 $(\mathrm{p}<$ 0.05）を認めたが，第 2 群と対照群とのあいだには有 意差を認めなかった。

7. 健常成人に抢ける末梢血の NK 活性では，OK$432 \mathrm{MCT}$ ×マルショョンを経口的に投与したところ, 投 与 3 日後にピークをみとめ 7 日後に投与前値に復し た，MCTェマルジョンのみを投与した群には NK 活 性の上昇は認められなかった（図９）。

8. 大腸癌患者 13 例に抢ける末梢血の $\mathrm{NK}$ 活性につ いては, OK-432 MCT ェマルジョン投与前に低値を示 したものが 5 例あったが，投与により 3 例が正常值に 復した。投与前に正常值であった症例は正常範团内の 変動を示した。手術前と手術 3 日後を比較検討すると， 術後 3 日目に低值を示した症例は 5 例であった。この 万ち 3 例は OK-432 MCT ェマルションの経口投与に
図 8 OK-432 MCT エマルジョン，OK-432水溶液投 与による細胞障害活性

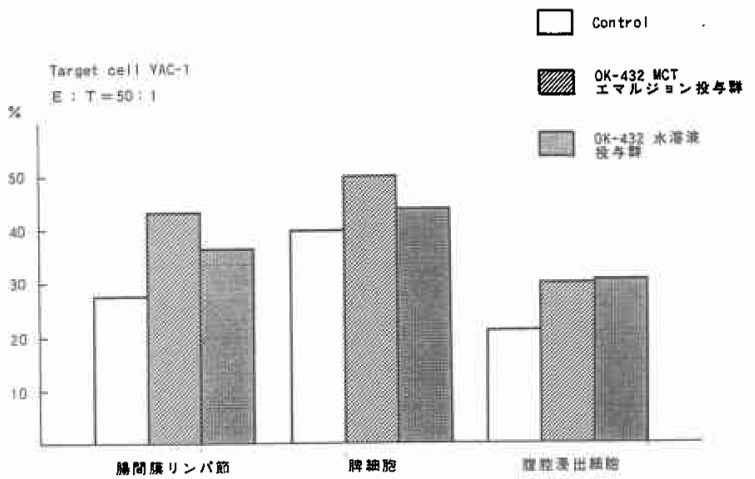

表 2 OK-432 MCT ェマルジョンおよび OK-432水 溶液経口投与による実験肝転移抑制効果

\begin{tabular}{|c|c|c|c|c|c|}
\hline & 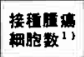 & 投与形䈍 & OK-432投与吾 & 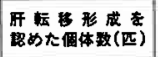 & 的输称形成平 \\
\hline $\begin{array}{c}\text { Group } 1 \\
(n=14)\end{array}$ & $2.5 \times 10^{6}$ & $\begin{array}{l}\text { OK-432 MCT } \\
\text { エマルジョン }\end{array}$ & $\begin{array}{c}8.0 \mathrm{KE} \\
(1.0 \times 2 \mathrm{~N})\end{array}$ & 6 & $42.97(7 / 14)^{\circ}$ \\
\hline $\begin{array}{r}\text { Group } 2 \\
(n=13)\end{array}$ & $2.5 \times 10^{6}$ & $\begin{array}{l}\text { OK-432 } \\
\text { 榕旅 }\end{array}$ & $\begin{array}{c}8.0 \mathrm{KE} \\
(1.0 \times 2 / 4)\end{array}$ & 7 & $53.1 \times(7 / 3)$ \\
\hline $\begin{array}{c}\text { Group } 3 \\
(n=18)\end{array}$ & $2.5 \times 10^{6}$ & コントロール & - & 2 & $90.07(2 / 18)$ \\
\hline
\end{tabular}

図 9 OK-432 MCT エマルジョン，MCT エマルジョ ン経口投与による健康男子成人の末梢血 NK 活性 の推移

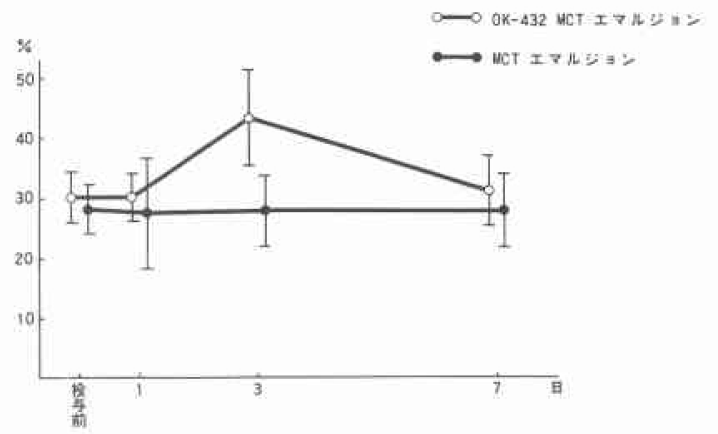

より正常に復したものが再度低下したものであった。 術後 7 日目では，低值を示したものは 5 例で，このう ち 2 例は合併症を括こした症例であった（図10）。

9. 担癌患者に括ける OKT4/OKT8は OK-432 $\mathrm{MCT}$ エマルジョンの経口投与により上昇し術後の低 下も汪とんどないことが認められた. Lue 7, Lue 11 の変動は OK-432 MCT エマルジョンの経口投与後に 
図10 OK-432 MCT エマルジョン術前経口投与によ る NK 活性の变化
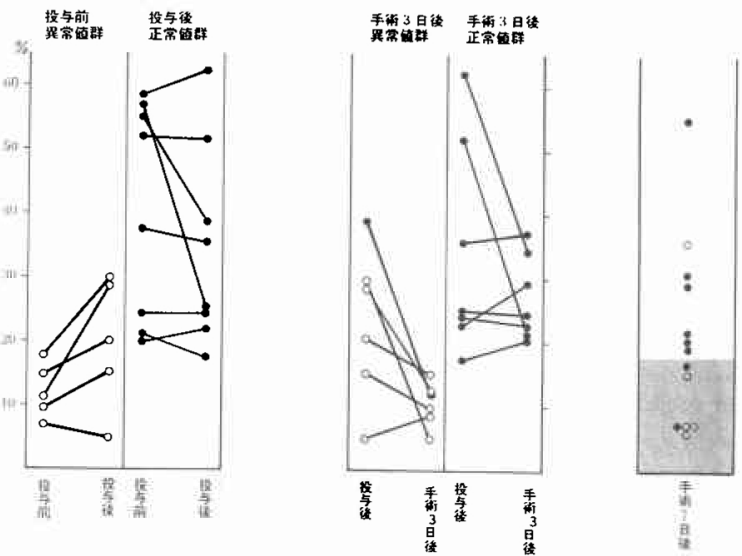

四11 OK-432 MCT エマルジョン経口投与症例に招 ける OKT4/OKT8

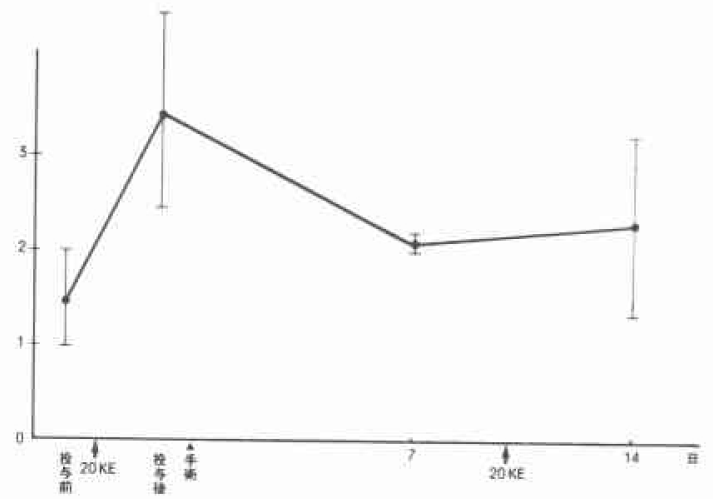

上昇したものが 6 例，不変のもの 5 例，低下したもの が7例認められた（図11，図12）。

\section{考 察}

OK-432の投与経路として，皮内，皮下 ${ }^{6)}$, 筋肉内 ${ }^{6)}$, 腫瘍内 ${ }^{7)}$, 動脈内 ${ }^{81}$, 静脈内 ${ }^{91}$, 門脈内 ${ }^{10}$, 胸腔内 ${ }^{11}$, 経

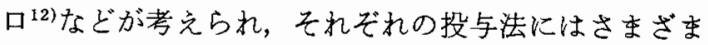
な利点と効果があるが，肝微小転移巣の抑制について は門脈への大量投与が最も効果的と思われる。しかし ながら，門脈内投与の臨床応用となると副作用あるい は投与期間の制限などの点で予防的治療としてはやや 実用性に欠ける面が多い。したがって，門脈内に高い 濃度の OK-432を得るためには経口的に投与すること が考光られるが, 従来, OK-432は消化管からは比較的 吸収され難いとされている。したがって，われわれは OK-432の吸収の増強を期待し, その吸収経路が加水分
图12 OK-432 MCT ェマルジョン経口投与した症例 の Leu $7(-)$ Leu $11(+)$, Leu $7(t)$ Leu $11(t)$ の変動
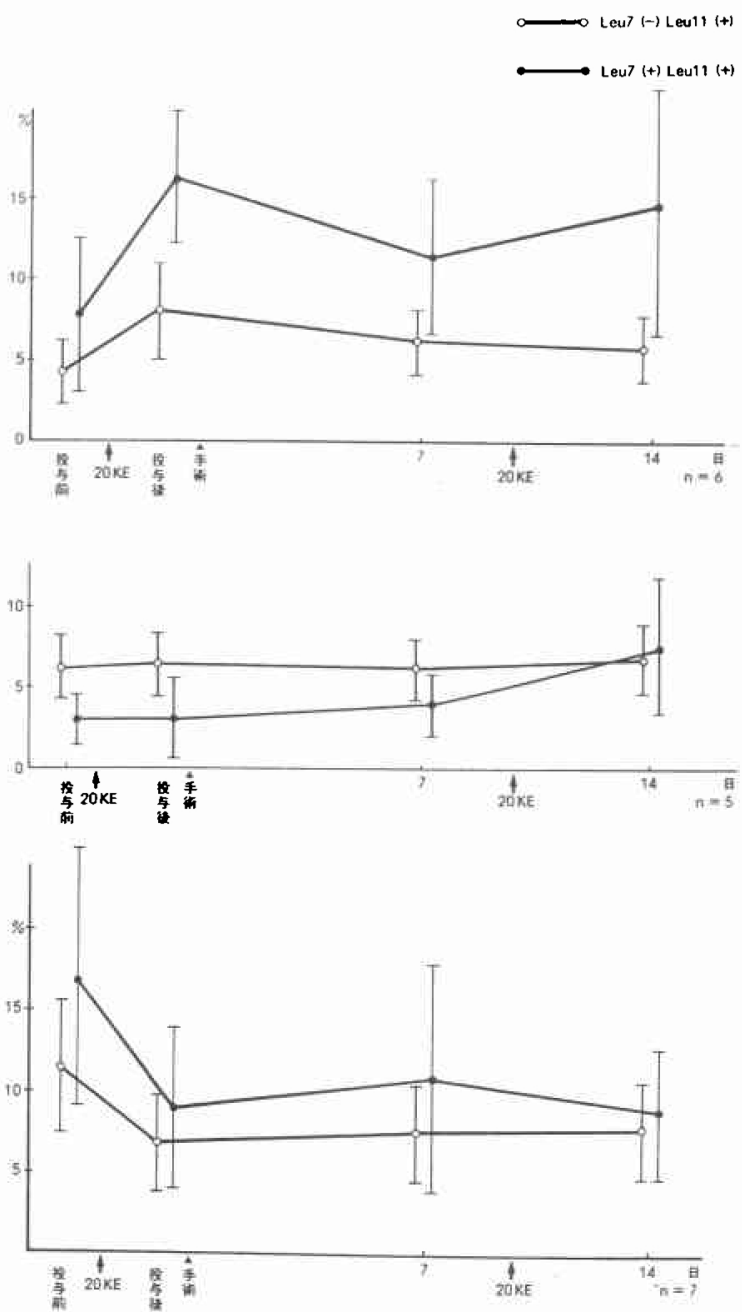

解を受けず，直接門脈系に移行する中鎖脂肪 (MCT) を用いてェマルジョン化して経口投与する方法を試み た. その効果を検討するため, ${ }^{99 m}$-Tc-OK-432-Sn コロ イドをMCTを用いてェマルション化しラットに経 腸的投与して門脈血中および臟器内分布をその放射能 活性の測定により求めた。門脈血中の放射能活性は OK-432 MCT ェマルジョン，および対照の OK-432水 溶液投与の両群とも速やかに上昇し, 約 20 分後に平衡 に達したが，いずれの測定時期においても前者は後者 の約10倍の放射能活性が認められた。 また, 贜器への 分布では両群とも肝に最も高い值が認められたが，両 
群間の葴器で比較すると OK-432 MCT ェマルジョン 投与群は OK-432水溶液投与群の約 8 倍の放射能活性 を認めた。これは，門脈内へ OK-432を直接投与しなく とも中鎖脂肪を用いてェマルション化し経口投与する ことで門脈内に比較的多量の OK-432が集中させるこ とが可能であることを示唆している，さらに，肝にお いて OK-432水溶液の約 8 倍の放射能活性が得られた ことは, 肝を Target とする本治療において，その有用 性を強く示唆しているものと考える. 高橋ら ${ }^{13)}$, Watanabe ら ${ }^{14}$ は長鎖脂肪を用いて5-Fuをェマル ショョ化して経口投与しているが，この際にはリンパ 系への移行が高いとしている.一方, 八木ら ${ }^{15)}$ は中鎖脂 肪を用いて5-Fuをエマルジョン化することにより，門 脈への移行が増強することを報告している。これは， 中鎖脂肪の吸収経路の特殊性によるものと思われる. 形態がこれらの薬剤とは異なる OK-432の吸収機序に ついてはさらに検討を要するものの，中鎖脂肪を用い たェマルジョン化の効果は一連の基礎実験により十分 期待できると考えている.

また, $\mathrm{C} 3 \mathrm{H} / \mathrm{He}$ マウスの細胞障害活性において検討 すると，OK-432投与群はいずれも $\mathrm{NK}$ 活性の上昇を 認めたが特に OK-432 MCT エマルション投与群が OK-432水溶液投与群上り高い傾向にあった。これは, OK-432を中鎖脂肪によりェマルジョン化して投与す ることが, 吸収増強のみならず全身性免疫能をより高 める効果を示唆しているものと考点られる ${ }^{16)}$.

臨床例に用いる前に OK-432 MCT ェマルジョンの 最も適切な投与時期を決定するため健康正常人の NK 活性を測定したところ，投与 3 日後にはそのピークを 認めた。 以上の結果より, 免疫能の最も上昇した時に 手術を施行するのが望むしいことから，臨床例につい ては手術 3 日前に OK-432 MCT エマルジョンを経口 投与した。実際の評価は困難なため, 末梢血の NK 活 性とリンパ球サブセットを用いて検討した，NK 活性 について考察すると, 術前に NK 活性の低下している 症例の正常化が OK-432 MCT エマルショョン経口投 与により得られた。しかし，これらの症例が一般的に 最も免疫能の低下するとされる術後 3 日目に再度, 投 与前の低值に復することも認められたことから, 術前 に NK 活性が低下している症例には術中の OK-432門 脈内投与がこの免疫能の再低下を予防できると考兄， 現在は両者の併用についても症例を重ねて検討中であ る.以上のような症例があるものの, 術後 3 日目の NK 活性は大半の症例が正常値を維持することから, 術前
に OK-432 MCT ェマルジョンを経口投与することの 意義は大きいと考えている。また，末梢血のリンバ球 サブセットについても，OKT4/OKT8は投与後上昇 し, Lue 7, Lue 11の上昇が認められる症例もあるこ となどから本剂の投与は全身性の免疫能をも增強せし めることを示唆していると考穴られる。 Leu 7, Leu 11 が投与後に低下している症例は術前の絶食，下剤の投 与など, プレパレーションの影響が考克られるが，さ らに検討を要すると思われる. 現在, 臨床応用開始約 2 年とまだ日も浅く実際の臨床上の評価は難しいが， 肝転移再発例はなく，またラットでの肝転移の実験に 抢いて肝転移を抑制する効果が高いことからも，臨床 に扔いても良好な結果が得られるものと思われる。

\section{結語}

代表的な BRM の 1 つである OK-432を中鎖脂肪に よりェマルショョン化し, 実験的, 臨床的に経口投与し て以下の結論を得た。

1） ${ }^{99 \mathrm{~m}}$-Tc 標識 OK·432を中鎖脂肪 (MCT) を用いて エマルションン化しドンリュウラットの十二指腸より投 与し経時的に門脈血中の放射能活性 (\%dpm/ml) を測 定した. 投与後20分でピークに達したが，すべての測 定点に打いて, OK-432 MCT ェマルション投与群は水 溶液投与群の約 10 倍高い值を示した。

2) 投与 90 分後に測定した体内の藏器分布は各臓器 に打いて, 99m-Tc-OK-432 MCT ェマルション投与群 は水溶液投与群の約 8.5 倍の放射能活性を示した。

3）マウスを用いた細胞障害活性において，OK-432 MCT エマルショョン投与群, 水溶液投与群とも脾細胞, 腸間膜リンパ節細胞, 腹腔浸出細胞に活性の上昇を認 めたが，前者は後者よりる高い傾向を示した。

4）腫湯細胞 $\mathrm{AH} 60 \mathrm{C}$ を用いたラットの肝転移実験 において，肝転移形成を認めなかったものは，OK-432 MCT ェマルジョン投与群は 14 匹 8 匹 (57.1\%), OK-432水溶液投与群は 13 匹 6 匹 $(46.1 \%)$, 無処置の ものは18匹中 2 匹 (11.1\%) で OK-432 MCT エマル ジョン経口投与群とのあいだに有意差を認めた。

5)男子健常成人に OK-432 MCT マルジョンを 経口投与し，末梢血の NK 活性を測定したところ，投 与 3 日後にピークに達し, 7 日後に投与前値に復した. $\mathrm{MCT}$ ェマルジョンのみを投与した群では NK 活性の 上昇を認めなかった。

6)大腸癌患者13例に対し OK-432 MCT ェマル ション20KEを術前経口投与し, 末梢血中の NK 活性 を投与前, 投与後, 手術 3,7 日後に測定した。投与 
前に低値を示した 5 例中 3 例が正常値に復した。

7) 大腸癌患者18例に対し OK-432 MCTェマル ジョンを術前 $20 \mathrm{KE}$ 投与し，フローサイトメトリーで 末梢血のリンパ球サブセットを解析した。 OKT4/ OKT8比は投与後上昇し術後も低下やず経過した。 Leu 7, Leu 11については，投与前に低值を示した 6 例が上昇したが，投与後に低下した７例は投与前は正 常值であり，その原因については，さらに検討を要す る.

以上の結果より OK-432を中鎖脂肪にてェマルショ ン化して経口投与することは肝転移の予防的な治療と して有用であることが示唆された。

\section{文献}

1）漆崎一朗, 塚越 茂編：癌と BRM. サイエンス フォーラム, 東京, $1982, \mathrm{p} 14-41$

2）田沢賢次, 笠木徳三, 永瀬敏明はか：外科手術後の 肝転移形成に対する予防的治療の研究. 外科診療 $58: 237-238,1988$

3）永瀬敏明：転移性肝癌の治療に関する実験的研究 ${ }^{32} \mathrm{P}$ 肝内照射療法による転移予防に関する実験. 日本大腸肛門病会誌 $39 ： 149-161,1983$

4）小田島成和：腹水肝癌の樹立, 長崎医会誌 38 : $428-448,1963$

5）宮川正澄：実験腫瘍学. 朝倉書店, 東京, 1966, p485 $-499$

6) Kurokawa T, Hattori T, Furue H: Clinical experiences with the streptococcal anticancer preparation OK-432 (NSC-B11620). Cancer Chemother Repo 56:211-220, 1972

7）豊田文一, 前坂明男：広汎な口蓋癌患者に対する
溶連菌制癌羭“PC-B-45”の使用経験。日耳鼻会誌 $71: 62-71,1968$

8）佐野秀一, 石黒敏史, 岩永力三ほ河：切除不能肝癌 に対するImmunochemotherapy. 診療と新薬 $16: 2819-2821,1983$

9）黑川利雄, 服部隆延, 古江 尚汪か：PC-B-45 の臨 床治験．癌の臨 $15 ： 1058-1062,1969$

10）田沢賢次：Biological response modifierを用い る外科手術後の肝転移形成に対する予防治療の可 能性. Ther Res 8：822-833，1988

11）太田和雄, 尾山 淳, 栗田宗次ほか：癌性胸膜炎に 対する溶連菌製剂 OK-432 の効果. 癌之化療 2： 255-262, 1972

12）土谷利晴, 児玉 宏, 戸部隆吉注か：ピシバニール (OK-432) 経口投与の試み（6報）一実験的消化管 腫煌に対する溶連菌製剂 OK-432の経口投与の in vivo 抗腫瘍免疫に及淁す影響. 日癌治療会誌 $20: 609-617,1985$

13）高橋俊雄, 河野研一,山口俊晴名か：胃癌に対する 5-FU Emulsion 術前経口投与療法. 手術 33 ： 21-26, 1979

14) Watanabe $T$, Nakao E, Cho $K$ et al: Basic experiments on administration of 5 -fluorouracil emulsion as adjuvant chemotherapy to surgical treatment for gastric cancer. Jpn J Surg 8 : $41-50,1978$

15）八木 実, 和田寛治, 小林清男ほか：フルオロウラ シルーMCTエマルションの投与で著効を示した 肝癌の治験例。基礎と臨 $17: 320-325,1983$

16）増山喜一, 田沢賢次, 笠木德三ほか：OK-432 中鎖 脂肪 (MCT) エマルション経口投与によるマウス 肺転移抑制効果. 日癌治療会誌 $23: 72-78,1988$ 